\title{
Stability Indicating RP-HPLC Method for Quantification of Impurities in Valsartan and Hydrochlorothiazide FDC Tablet Dosage Form
}

\author{
Hari Kishan Reddy Ganthi',2, Raveendra Reddy P1*, Young Jun Park², So Jin Park², Woo Hyong Cho \\ ${ }^{1}$ Department of Chemistry, Sri Krishnadevaraya University, Anantapur, India \\ ${ }^{2}$ Celltrion Chemical Research Institute, Yongin, South Korea \\ Email: *hari.reddy0412@gmail.com
}

How to cite this paper: Ganthi, H.K.R., Reddy P, R., Park, Y.J., Park, S.J. and Cho, W.H. (2016) Stability Indicating RP-HPLC Method for Quantification of Impurities in Valsartan and Hydrochlorothiazide FDC Tablet Dosage Form. American Journal or Analytical Chemistry, 7, 816-839. http://dx.doi.org/10.4236/ajac.2016.711072

Received: September 26, 2016 Accepted: November 27, 2016 Published: November 30, 2016

Copyright $\odot 2016$ by authors and Scientific Research Publishing Inc. This work is licensed under the Creative Commons Attribution International License (CC BY 4.0).

http://creativecommons.org/licenses/by/4.0/ (c) (i) Open Access

\begin{abstract}
A stability-indicating RP-HPLC method has been developed and validated for simultaneous determination of Valsartan \& Hydrochlorothiazide and their impurities in FDC (Fixed Dose Combination) tablet dosage form. The method was developed using L1 column $(250 \times 4.6 \mathrm{~mm} ; 5 \mu \mathrm{m})$ with gradient elution using the mobile phase consisting of solvent-A ( $0.1 \%$ Ortho phosphoric acid) and solvent-B (100\% Acetonitrile); the gradient program $\left(\mathrm{T}_{\min } / \% \mathrm{~B}\right)$ was set as $0 / 10,5 / 10,20 / 60,40 / 60,41 / 10$ and $50 / 10$. The eluted compounds were monitored at $265 \mathrm{~nm}$. The developed method was validated as per ICH guidelines with respect to specificity, linearity, limit of detection, limit of quantitation, accuracy, precision and robustness. The influence of Acid, Alkaline, Oxidative, Photolytic, Thermal and Humidity stress conditions, on drug product was studied. The limit of quantification results of Valsartan, Hydrochlorothiazide and their impurities are, VAL: $0.303 \mu \mathrm{g} / \mathrm{mL}, \mathrm{HCTZ}: 0.019 \mu \mathrm{g} / \mathrm{mL}$, VAL RC-B: $0.085 \mu \mathrm{g} / \mathrm{mL}$, VAL RC-C: $0.327 \mu \mathrm{g} / \mathrm{mL}$, HCT RC-A: $0.017 \mu \mathrm{g} / \mathrm{mL}$, CTZ: 0.080 $\mu \mathrm{g} / \mathrm{mL}$ and 5-Chloro HCT: $0.047 \mu \mathrm{g} / \mathrm{mL}$. The proposed method is suitable for the estimation of Valsartan \& Hydrochlorothiazide impurities in tablets dosage form.
\end{abstract}

\section{Keywords}

Valsartan, Hydrochlorothiazide, RP-HPLC, Impurities, Method Validation

\section{Introduction}

Valsartan \& Hydrochlorothiazide are available with the brand name of "Diovan HCTZ" in the form of immediate-release tablets with the dosage strengths VAL/HCTZ: 80 
$\mathrm{mg} / 12.5 \mathrm{mg}, 160 \mathrm{mg} / 25 \mathrm{mg}, 160 \mathrm{mg} / 12.5 \mathrm{mg}, 320 \mathrm{mg} / 25 \mathrm{mg}$ and $320 \mathrm{mg} / 12.5 \mathrm{mg}$. Diovan HCTZ is a combination of valsartan, an orally active, specific angiotensin II receptor blocker (ARB) acting on the AT1 receptor subtype, and hydrochlorothiazide, a diuretic [1].

Valsartan (VAL), a nonpeptide molecule, is chemically described as N-(1-oxopentyl)-N[[2'-(1H-tetrazol-5-yl)[1,1'-biphenyl]-4-yl]methyl]-L-Valine. Its empirical formula is $\mathrm{C}_{24} \mathrm{H}_{29} \mathrm{~N}_{5} \mathrm{O}_{3}$ and molecular weight is 435.5 gms/mol. Valsartan is a white, practically white fine powder. It is soluble in ethanol and methanol and slightly soluble in water [1].

Hydrochlorothiazide (HCTZ) is a thiazide diuretic, chemically described as 6-chloro3,4-dihydro-2H-1,2,4-benzothiadiazine-7-sulfonamide 1,1-dioxide. Its empirical formula is $\mathrm{C}_{7} \mathrm{H}_{8} \mathrm{ClN}_{3} \mathrm{O}_{4} \mathrm{~S}_{2}$ and molecular weight is $297.73 \mathrm{gms} / \mathrm{mol}$. HCTZ is a white, practically white, odorless, crystalline powder. It is slightly soluble in water; freely soluble in sodium hydroxide solution, in n-butylamine, and in dimethylformamide; sparingly soluble in methanol; and insoluble in ether, in chloroform, and in dilute mineral acids [1].

Monographs for VAL \& HCTZ drug substance and drug product are available in United States Pharmacopoeia (USP) and in European Pharmacopoeia (EP) [2] [3]. And $\mathrm{VAL}+\mathrm{HCTZ}$ tablets monograph is available in USP [2]. Literature survey reveals that Protein Precipitation/HPLC, HPLC/Liquid extraction, and UV methods for VAL [4] [5] [6] [7] and HPLC, GC/MS methods [8] [9] for HCTZ \& HPLC, UPLC, UV, Capillary electrophoresis, First derivative UV, HPLC with Fluorimetric detection, LC/MS and Micellar electro kinetic chromatographic methods for simultaneous estimation of VAL + HCTZ in tablet dosage forms are available [10]-[19]. And Zhang Hui et al. [20] \& Chen Xiao et al. [21] reported a method for the estimation of related substances in VAL \& HCTZ tablet dosage form.

The objective of this article is to present a stability-indicating method to separate and estimate VAL \& HCTZ and its related compounds precisely and accurately, due to that HCTZ-1 \& HCTZ-2 impurities were not well separated from each other and peak shapes were found not symmetric in references [2] [20] [21]. In the present work, a simple, fast, accurate and precise liquid chromatographic method was developed for the separation and determination of VAL \& HCTZ and its impurities.

\section{Material and Methods}

\subsection{Reagents and Chemicals}

The purity of all chemicals used was above 99\%. Standards of VAL, HCTZ and their impurities were supplied by Celltrion, South Korea. The chemical structures of VAL \& HCTZ and their impurities are presented in Figure 1. The purities are respectively, VAL (99.4\%), HCTZ (100\%) and their impurities VAL RC-B [VAL-1] (97.0\%), VAL RC-C [VAL-2] (98\%), HCT RC-A [HCTZ-1] (99\%), CTZ [HCTZ-2] (99.6\%), 5CHLORO HCT [HCTZ-3] (99.1\%) and HCT DIMER [HCTZ-4] (84.5\%). The chemicals and reagents manufacturer details are as follows, acetonitrile (HPLC-Gradient 
<smiles>CCCCC(=O)N(Cc1ccc(-c2ccccc2-c2nnn[nH]2)cc1)[C@@H](C(=O)O)C(C)C</smiles>

\section{A. Valsartan (VAL)}<smiles>NS(=O)(=O)c1cc2c(cc1Cl)N=CNS2(=O)=O</smiles>

6-Chloro-2-H-1,2,4benzothiadiazine-7sulfonamide-1-1-dioxide

D. HCTZ-2 /CTZ<smiles>CCCC(=O)N(Cc1ccc(-c2ccccc2-c2nnn[nH]2)cc1)[C@@H](C(=O)O)C(C)C</smiles>

(N-butyryl-N- $\{[2$ '-(1H-tetrazole-

5yl) biphenyl-4-yl]-methyl\}-LValine)

\section{G. VAL-1 (VAL RC-B)}<smiles>NS(=O)(=O)c1cc2c(cc1Cl)NCNS2(=O)=O</smiles>

\section{B. Hydrochlorothiazide (HCTZ)}

4-Amino-6-chloro-1,3benzenedisulfonamide

\section{HCTZ-1 /HCT RC-A}

5,6-Dichloro-3,4-dihydro-2H1,2,4-benzothiadiazine-7sulfonamide 1,1-dioxide E. HCTZ-3 /5-Chloro HCT<smiles>Nc1cc(Cl)c(S(N)(=O)=O)cc1S(N)(=O)=O</smiles><smiles>NS(=O)(=O)c1cc2c(c(Cl)c1Cl)NCNS2(=O)=O</smiles><smiles>CS(=O)(=O)c1cc2c(cc1Cl)NCNS2(=O)=O</smiles>

6-Chloro-N-[(6-chloro-7sulfamoyl-2,3-dihydro-4H1,2,4-benzothiadiazine-4-yl 1,1dioxide) methyl]3,4-dihydro2H-1,2,4-benzothiadiazine-7sulfonamide 1,1-dioxide F. HCTZ-4/ HCT Dimer<smiles>CCCCC(=O)N(Cc1ccc(-c2ccccc2-c2nnn[nH]2)cc1)[C@@H](C(=O)OCc1ccccc1)C(C)C</smiles>

((S)N-Valeryl-N-([2'-(1Htetrazole-5yl) biphenyl-4-yl]methyl) Valine benzyl ester)

H. VAL-2 (VAL RC-C)

Figure 1. Chemical structures of valsartan, hydrochlorothiazide and their impurities: A. Valsartan (VAL); B. Hydrochlorothiazide (HCTZ); C. HCTZ-1; D. HCTZ-2; E. HCTZ-3; F. HCTZ-4; G. VAL-1; H. VAL-2. 
grade; J T Baker), ortho phosphoric acid (Analytical grade; Sigma Aldrich) and highly purified water for analysis prepared by using Millipore water purification system (Millipore USA).

\subsection{Instruments}

Standard and test solutions were prepared using 50\% Acetonitrile in Milli-Q water as diluent and analyzed by HPLC (Agilent 1260 infinity; Germany). HPLC system equipped with a quaternary pump, auto sampler with thermostat, column compartment, and PDA detector. Using Chemstation software the chromatograms were monitored and integrated. Hydrolysis stress studies performed using digital water bath (Grant). Samples stressed in dry air oven for thermal stress studies (Thermo scientific). Mobile phase was degassed in a sonicator (Powersonic 420; Labtech) and $0.45 \mu \mathrm{m} \mathrm{Ny-}$ lon membrane filters (PALL life sciences, USA) used for mobile phase filtration.

\subsection{Chromatographic Conditions}

The chromatographic column, Waters Symmetry shield RP18 $(250 \times 4.6 \mathrm{~mm} ; 5 \mu \mathrm{m})$; and mobile phase consisting solvent $\mathrm{A}$ and $\mathrm{B}$ used for method development. 0.1\% phosphoric acid ( $1 \mathrm{~mL}$ of ortho phosphoric acid in $1000 \mathrm{~mL}$ of milli-Q water) was used as solvent- $\mathrm{A}$ and $100 \%$ acetonitrile was used as solvent- $\mathrm{B}$. The gradient elution (Time

${ }_{\min } / \%$ of Solvent-B) was set as $0 / 10,5 / 10,20 / 60,40 / 60,41 / 10$ and 50/10, mobile phase flow rate was $1.0 \mathrm{~mL} \cdot \mathrm{min}^{-1}$, column oven temperature at $25^{\circ} \mathrm{C}$ and the chromatograms were monitored at $265 \mathrm{~nm}$. Standard and sample solutions were injected at $20 \mu \mathrm{L}$ of injection volume and $100 \%$ Acetonitrile used as needle wash solvent to reduce carryover from injector.

\section{Experimental}

\subsection{Preparation of System Suitability Solution}

A stock solutions of VAL, HCTZ, HCTZ-1 \& VAL-1 $\left(640 \mu \mathrm{g} \cdot \mathrm{mL}^{-1}\right.$ of VAL, $100 \mu \mathrm{g} \cdot \mathrm{mL}^{-1}$ of HCTZ, $500 \mu \mathrm{g} \cdot \mathrm{mL}^{-1}$ of HCTZ-1 and $32 \mu \mathrm{g} \cdot \mathrm{mL}^{-1}$ of VAL-1) were prepared by dissolving appropriate amount of drugs in diluent (Milli-Q water and Acetonitrile 50:50 $\mathrm{v} / \mathrm{v})$. Working solutions of $32 \mu \mathrm{g} \cdot \mathrm{mL}^{-1}$ of VAL, $5 \mu \mathrm{g} \cdot \mathrm{mL}^{-1}$ of $\mathrm{HCTZ}$, and $25 \mu \mathrm{g} \cdot \mathrm{mL}^{-1}$ of HCTZ-1 and $32 \mu \mathrm{g} \cdot \mathrm{mL}^{-1}$ of VAL-1 were prepared by spiking VAL, HCTZ \& HCTZ-1 stock solutions to VAL-1 stock solution. Individual stock solutions were prepared in diluent.

\subsection{Preparation of Standard Solution}

Working solution of $3.2 \mu \mathrm{g} \cdot \mathrm{mL}^{-1}$ of VAL, $0.5 \mu \mathrm{g} \cdot \mathrm{mL}^{-1}$ of $\mathrm{HCTZ}$, and $2.5 \mu \mathrm{g} \cdot \mathrm{mL}^{-1}$ of HCTZ-1 and $3.2 \mu \mathrm{g} \cdot \mathrm{mL}^{-1}$ of VAL-1 standard solution is prepared by diluting appropriate volume of above system suitability solution with diluent.

\subsection{Preparation of Test Solutions}

Here test solution is prepared at concentration of $1600 \mu \mathrm{g} \cdot \mathrm{mL}^{-1}$ for VAL and 250 
$\mu \mathrm{g} \cdot \mathrm{mL}^{-1}$ for HCTZ to get sufficient LOQ values, good peak shapes and adequate resolution between all the peaks. Hence second dilution is proposed for valsartan test solution preparation.

Test stock solution preparation (For $80 / 12.5 \mathrm{mg}, 160 / 12.5 \mathrm{mg} \& 160 / 25 \mathrm{mg}$ Strengths):

10 tablets of each strength taken into a $250 \mathrm{~mL}$ flask, dispersed the tablets with $5 \mathrm{~mL}$ of water. Added $70 \%$ of the diluent of total volume and sonicated for $15 \mathrm{~min}$ and diluted to volume with diluent. The above solutions were centrifuged at $3000 \mathrm{rpm}$ for 10 min. The supernatant liquid was further filtered through $0.45 \mu \mathrm{m}$ PVDF (or) Nylon syringe filters.

Test solution preparation-HCTZ:

For $80 / 12.5 \mathrm{mg} \& 160 / 12.5 \mathrm{mg}$ :

Dilute $5 \mathrm{~mL}$ of the above clear test stock solution to $10 \mathrm{~mL}$ with diluent and mix well.

For 160/25 mg:

Dilute $5 \mathrm{~mL}$ of the above clear test stock solution to $20 \mathrm{~mL}$ with diluent and mix well.

Test solution preparation-VAL:

For $80 / 12.5 \mathrm{mg}$ :

Dilute $5 \mathrm{~mL}$ of the above clear test stock solution to $10 \mathrm{~mL}$ with diluent and mix well.

For 160/12.5 mg \& 160/25 mg:

Dilute $5 \mathrm{~mL}$ of the above clear test stock solution to $20 \mathrm{~mL}$ with diluent and mix well.

Test stock solution preparation (For 320/12.5 mg \& 320/25 mg Strengths):

5 tablets of each strength taken into a $250 \mathrm{~mL}$ flask, dispersed the tablets with $5 \mathrm{~mL}$ of water. Added $70 \%$ of the diluent of total volume and sonicated for $15 \mathrm{~min}$ and diluted to volume with diluent. The above solutions were centrifuged at $3000 \mathrm{rpm}$ for $10 \mathrm{~min}$. The supernatant liquid was further filtered through $0.45 \mu \mathrm{m}$ PVDF (or) Nylon syringe filters.

Test solution preparation-HCTZ:

For $320 / 12.5 \mathrm{mg}$ :

Use above clear test stock solution.

For 320/25 mg:

Dilute $5 \mathrm{~mL}$ of the above clear test stock solution to $10 \mathrm{~mL}$ with diluent and mix well.

Test solution preparation-VAL:

For 320/12.5 mg \& 320/25 mg:

Dilute $5 \mathrm{~mL}$ of the above clear test stock solution to $20 \mathrm{~mL}$ with diluent and mix well.

Analysis of impurities from Valsartan and Hydrochlorothiazide Tablets:

Inject $20 \mu \mathrm{L}$ of the blank (diluent), System suitability solution, Standard solution in replicate and Test solution for HCTZ and for VAL into the HPLC system, record the chromatograms, and measure the responses of the all impurity peaks. Calculate \% of HCTZ-1, HCTZ-2, HCTZ-3 and HCTZ-4 against HCTZ peak response from standard solution and, VAL-1, VAL-2 and Unknown impurities against VAL peak response from standard solution (Figure 2(A) \& Figure 2(B)). 


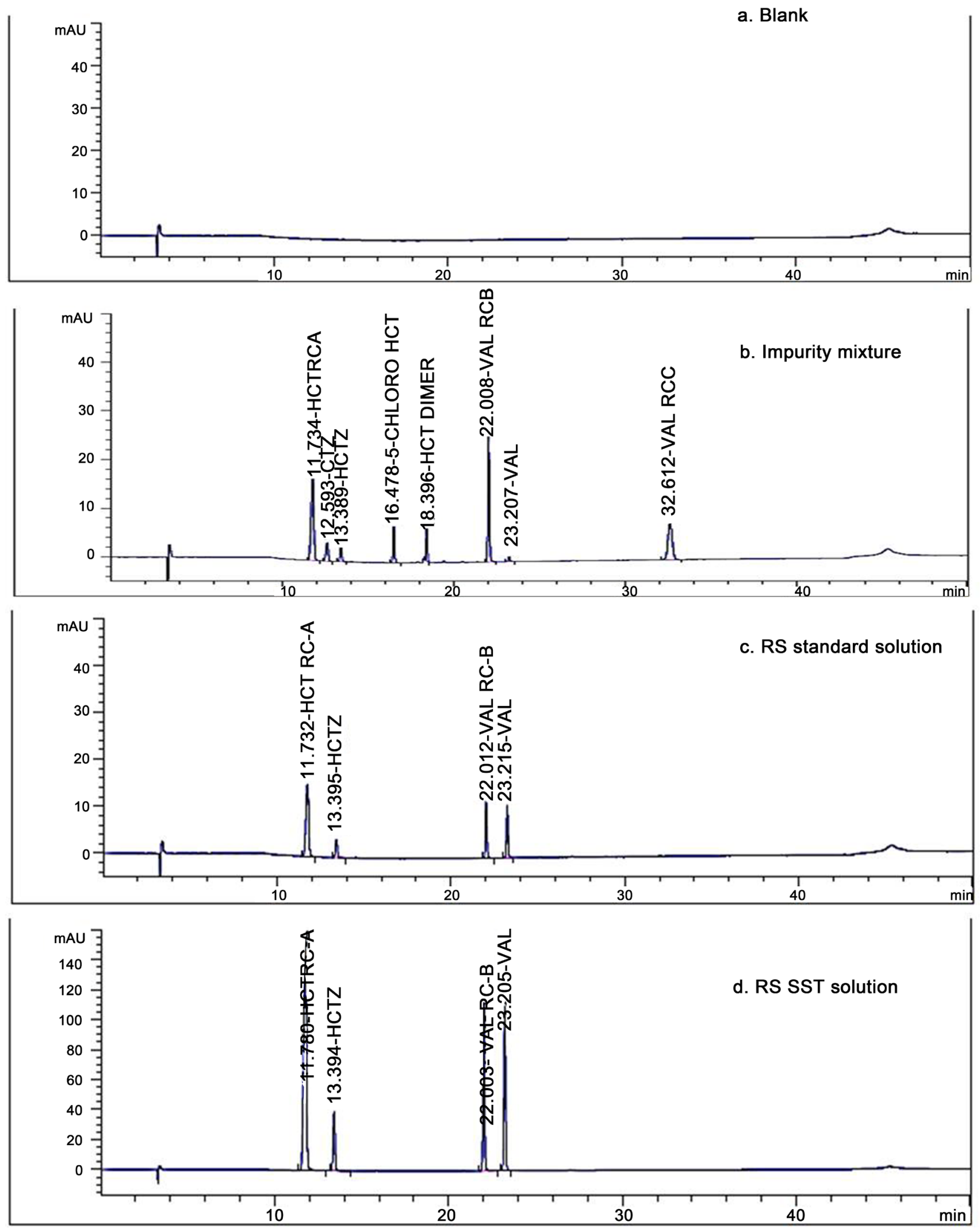

(A) 

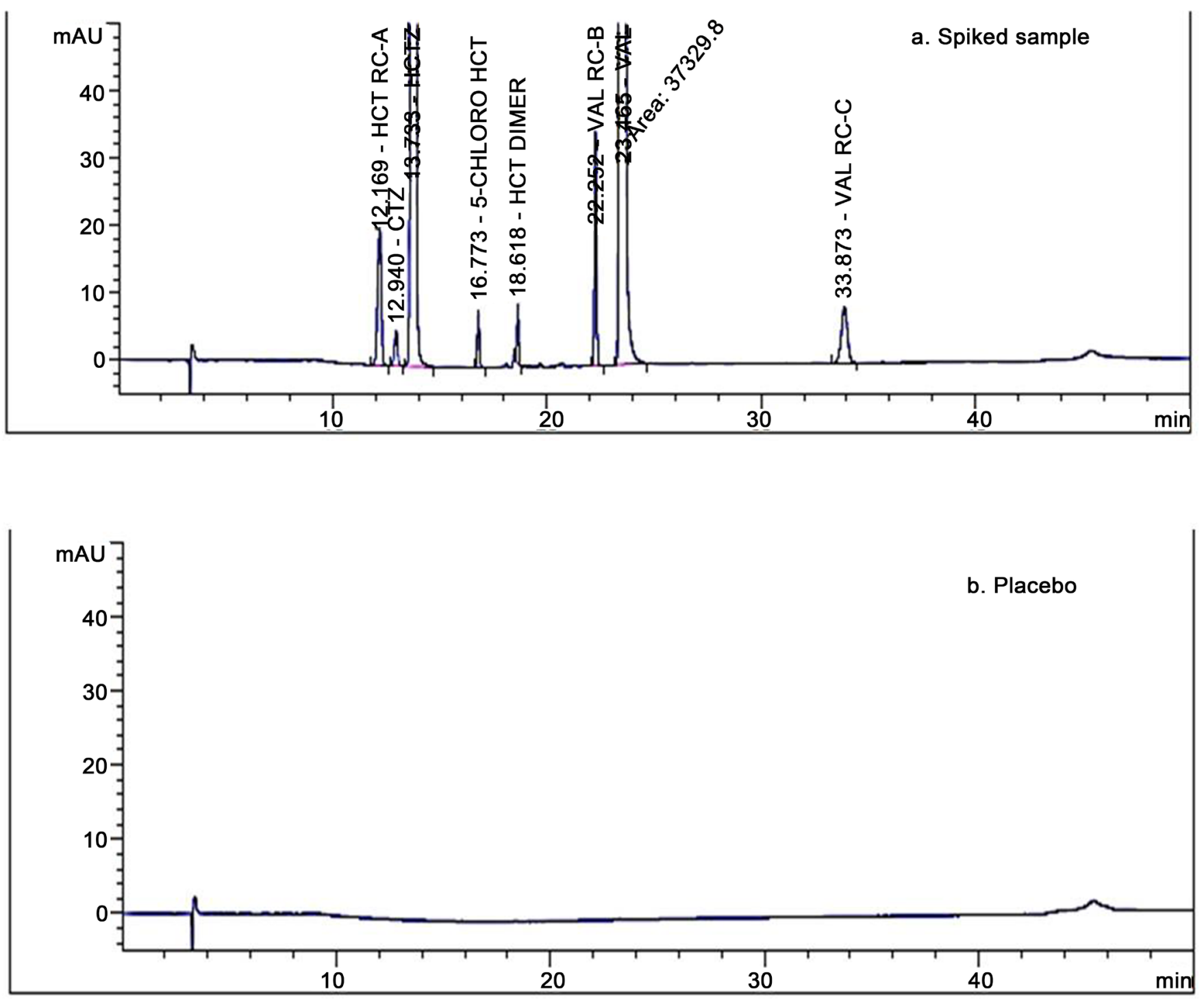

(B)

Figure 2. (A) Typical chromatograms of valsartan and hydrochlorothiazide at $265 \mathrm{~nm}$ (a. Blank, b. Impurity Mixture, c. RS Standard Solution and d. RS SST solution); (B) Typical chromatograms of valsartan and hydrochlorothiazide at $265 \mathrm{~nm}$ (a. Spiked sample and b. Placebo).

\subsection{Method Validation}

The objective of validation of an analytical procedure is to demonstrate that it is suitable for its intended purpose. The method was validated according to International Council for Harmonisation Q2 (R1) guidelines [22] for validation of analytical procedures in order to determine the specificity, linearity, limit of detection, limit of quantification, accuracy, precision and robustness.

Here HCTZ-4 impurity is not considered to determine the specificity, linearity, limit of detection, limit of quantification, accuracy, precision and robustness of method validation parameters, and only considered for identification purpose, due to not stable at solution state. 


\subsection{Solution Stability}

The stability of VAL, HCTZ and their impurities was determined by leaving spiked sample solution in a tightly capped volumetric flask at room temperature $\left(25^{\circ} \mathrm{C}\right)$ and in refrigerator $\left(5^{\circ} \mathrm{C}\right)$ up to $48 \mathrm{hrs}$ and measuring the amounts of the five impurities at every $24 \mathrm{hrs}$.

\subsection{Specificity}

Specificity is the ability of the method to confirm the non-interference from blank and placebo at the retention time of analyte peaks and at its potential impurities; and to measure the analyte response in the presence of its potential impurities. This study was carried out in presence of its six impurities. Forced degradation studies performed on drug product at the concentration of $1600 \mu \mathrm{g} \cdot \mathrm{mL}^{-1}(\mathrm{VAL})$ and $250 \mu \mathrm{g} \cdot \mathrm{mL}^{-1}$ of $\mathrm{HCTZ}$, to prove the stability indicating nature of the method.

Samples were stressed intentionally to degrade, at the condition of UV light (200 watt $\left.\mathrm{hr} / \mathrm{m}^{2}\right)$, Sun-light (1.2 Mill lux hrs), thermal $\left(60^{\circ} \mathrm{C}\right.$ for $\left.15 \mathrm{hr}\right)$, acid $\left(1 \mathrm{~N} \mathrm{HCl}\right.$ at $60^{\circ} \mathrm{C}$ for $12 \mathrm{hr}$ ), base $\left(1 \mathrm{~N} \mathrm{NaOH}\right.$ at $60^{\circ} \mathrm{C}$ for $12 \mathrm{hr}$ ), water (at $60^{\circ} \mathrm{C}$ for $12 \mathrm{hr}$ ), oxidation ( $10 \%$ $\mathrm{H}_{2} \mathrm{O}_{2}$ at RT for $12 \mathrm{hr}$ ) and humidity (90\% RH for 7 days) respectively to evaluate the ability of the proposed method to separate VAL and HCTZ from their degradation products. Using PDA detector the stress samples peak purity was checked for VAL and HCTZ peaks.

\subsection{Linearity}

Linearity test solutions for VAL, HCTZ and their impurities were prepared by diluting stock solutions to required concentrations. The solutions were prepared at ten concentration levels from LOQ to $200 \%$ of the specification level $1.0 \%$ for HCTZ-1, $0.5 \%$ for HCTZ-2 \& HCTZ-3, 0.2\% for VAL-1, VAL-2, and VAL \& HCTZ. The peak area versus concentration data was treated by least-squares linear regression analysis.

\subsection{Limit of Detection (LOD) and Quantification (LOQ)}

The LOD and LOQ for VAL and HCTZ and their impurities were determined at a signal-to-noise ratio of 3:1 and 10:1, respectively, by injecting a series of dilute solutions with known concentrations. Precision study was also carried out at the LOQ level by injecting six individual preparations and calculated \% RSD.

\subsection{Accuracy}

Standards of VAL, HCTZ and their impurities were spiked at different concentration levels namely LOQ, $50 \%, 100 \%, 150 \%$ and $200 \%$ of the specification level with respect to their test concentration in triplicate and evaluated for accuracy of impurities. The percentage of recoveries for VAL, HCTZ and their impurities were calculated.

\subsection{Precision}

The precision of the method was verified by injecting six individual preparations of 
dosage form (VAL $160 \mathrm{mg}$ and HCTZ $12.5 \mathrm{mg}$ ) spiked with its impurities of their specification level. VAL impurities are spiked at $0.2 \%$ with respect to VAL concentration $1600 \mu \mathrm{g} \cdot \mathrm{mL}^{-1}$ and HCTZ impurities are spiked at $1.0 \%$ (for HCTZ-1) and $0.5 \%$ (for HCTZ-2 \& HCTZ-3) with respect to HCTZ concentration $250 \mu \mathrm{g} \cdot \mathrm{mL}^{-1}$. \% RSD of each impurity was calculated.

The same experiment was repeated on different day with different chromatographic system and different analyst to find variability.

\subsection{Robustness}

To determine the robustness of the method, experimental conditions were deliberately altered and the tailing factors, resolution between VAL, HCTZ and their impurities were recorded. The effect of flow rate was evaluated at 0.9 and $1.1 \mathrm{~mL} \cdot \mathrm{min}^{-1}$ instead of $1.0 \mathrm{~mL} \cdot \mathrm{min}^{-1}$. The effect of the column temperature was studied at $20^{\circ} \mathrm{C}$ and $30^{\circ} \mathrm{C}$ instead of $25^{\circ} \mathrm{C}$.

\section{Results \& Discussion}

\subsection{Method Development}

The main target of the chromatographic method is to get the separation of impurities namely HCTZ-1, HCTZ-2, HCTZ-3 and HCTZ-4 of HCTZ \& VAL-1 and VAL-2 of $\mathrm{VAL}$ and the degradation products generated during stress studies from the analyte peaks along with the actives.

A blended solution containing VAL impurities are spiked at $0.2 \%$ with respect to VAL concentration of $1600 \mu \mathrm{g} \cdot \mathrm{mL}^{-1}$ and HCTZ impurities are spiked at $1.0 \%$ (for HCTZ-1) and 0.5\% (for HCTZ-2, HCTZ-3 \& HCTZ-4) with respect to HCTZ concentration of $250 \mu \mathrm{g} \cdot \mathrm{mL}^{-1}$ was prepared in diluent and used for the method's development. Initial experiments were performed using USP drug product monograph, with acetonitrile:water:Trifluoroacetic acid (10:90:0.1 v/v/v) as solvent-A and acetonitrile:water: Trifluoroacetic acid (90:10:0.1 v/v/v) as solvent-B with two different brand chromatographic columns namely ACE-5 \& Hypersil Gold (C-18, 125-mm 3.0-mm, $5 \mu \mathrm{m}$ particles) and found HCTZ-1, HCTZ-2 peaks merged together and closely eluted to HCTZ peak, and HCTZ-1 impurity peak shape found not sharp.

Further changed $0.1 \%$ OPA (Ortho phosphoric acid) as solvent-A and 100\% acetonitrile as solvent- $\mathrm{B}$ and experiments were performed using different $\mathrm{C} 18$ brand columns namely Hypersil BDS C18, Inertsil ODS-3V, Waters symmetry shield RP-18 and Zorbax SB C18 having dimensions $250 \mathrm{~mm}, 4.6 \mathrm{~mm}, 5 \mu \mathrm{m}$ particles. And results found HCTZ-1, HCTZ-2 peak shapes not symmetric except with Waters symmetry shield RP-18 column.

Using $0.1 \%$ TFA (Trifluoroacetic acid) as solvent-A in place of $0.1 \%$ OPA, experiments were performed using same brand C18 columns Hypersil BDS C18, Waters symmetry shield RP-18 and Zorbax SB C18 having dimensions $250 \mathrm{~mm}, 4.6 \mathrm{~mm}, 5 \mu \mathrm{m}$ particles. Results found HCTZ-1, HCTZ-2 peak shapes not symmetric except with Waters symmetry shield RP-18 column. 
Among these experiments, $0.1 \%$ OPA as solvent-A and $100 \%$ acetonitrile as solvent-B using Waters symmetry shield RP- $18,250 \mathrm{~mm}, 4.6 \mathrm{~mm}, 5 \mu \mathrm{m}$ particles column had shown better resolution, peak shapes and responses. However to improve the resolution between HCTZ-1; HCTZ-2 \& HCTZ peaks, effect of variations was studied with respect to flow rate and column oven temperature. Trial chromatograms are shown in Figures 3(A)-(C).
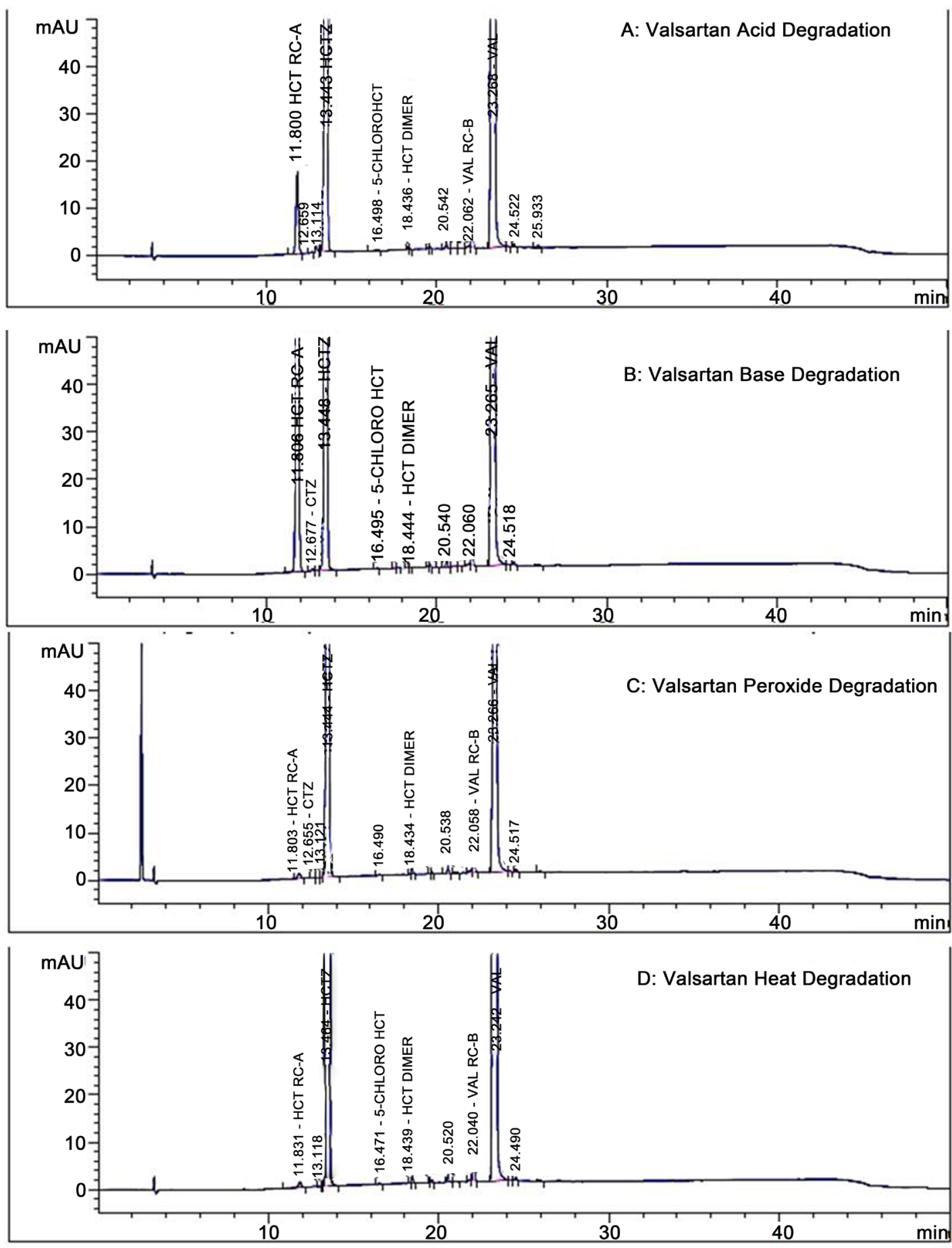

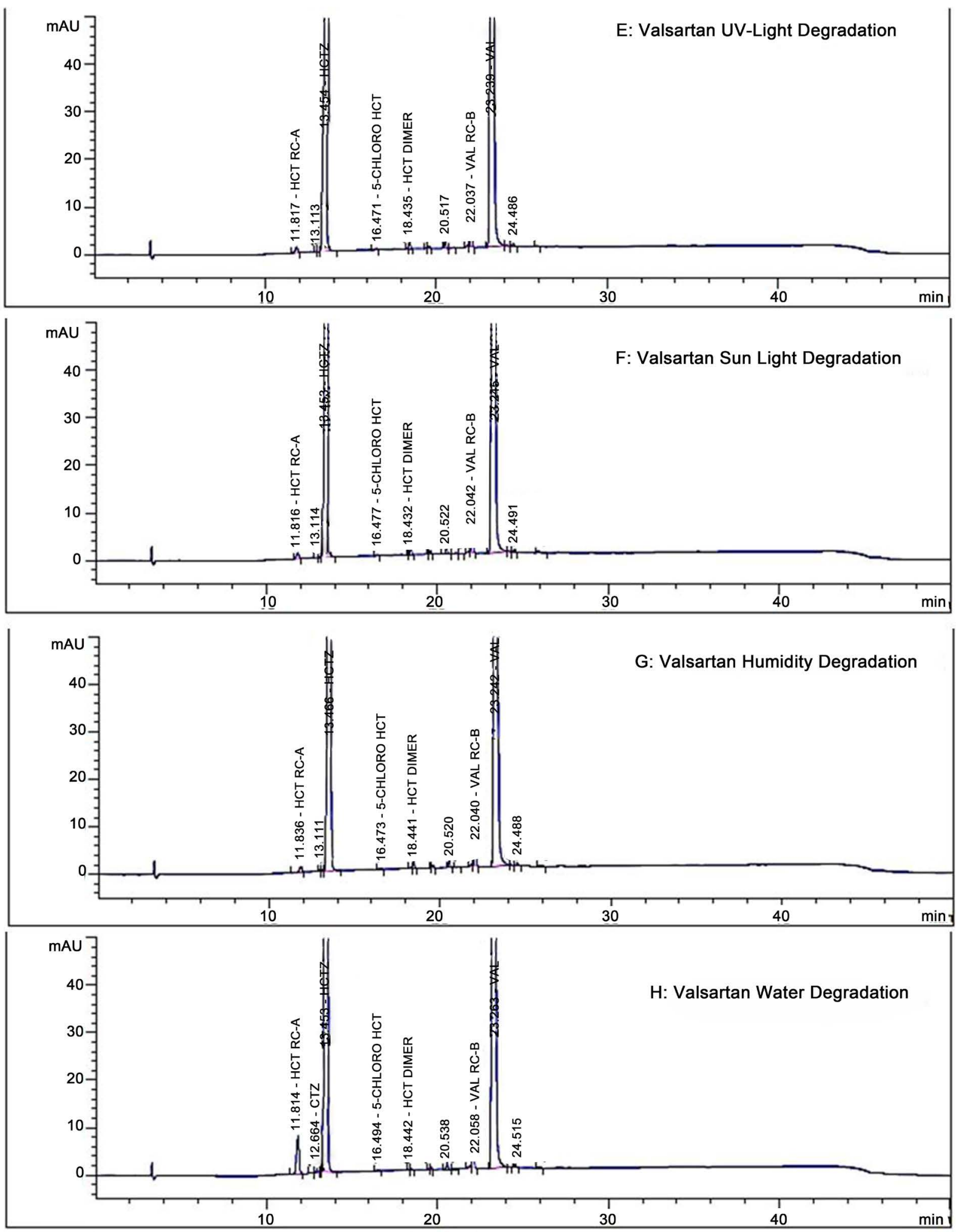

Figure 3. Typical chromatograms of valsartan at $265 \mathrm{~nm}$ (forced degradation study) (A. valsartan acid degradation; B. valsartan base degradation; C. valsartan peroxide degradation and D. valsartan heat degradation); Typical chromatograms of valsartan at $265 \mathrm{~nm}$ (forced degradation study) (E. valsartan uv-light degradation; F. valsartan sun-light degradation; G. valsartan humidity degradation and $H$. valsartan water degradation). 
Based on the experiments with different gradient programs a gradient program $\left(\mathrm{T}_{\min } / \% \mathrm{~B}\right)$ was set as $0 / 10,5 / 10,20 / 60,40 / 60,41 / 10$ and $50 / 10$ at detection wavelength $265 \mathrm{~nm}$ with the mobile phase consists of solvent-A (0.1\% OPA) and solvent-B (100\% acetonitrile), using Waters symmetry shield RP-18, $250 \times 4.6 \mathrm{~mm} ; 5 \mu \mathrm{m}$ column was found suitable for separation of VAL, HCTZ and its impurities from each other at column oven temperature of $25^{\circ} \mathrm{C}$. The resolution between any two consecutive peaks is more than 2.0 and shapes of all peaks were found symmetric.

The above chromatographic conditions were suitable in separating VAL, HCTZ and its impurities from one other. Details of relative retention time, relative response factor, resolution and tailing factor values are summarized in Table 1.

\subsection{Wavelength Justification}

Wavelength was selected based on wavelength maxima of VAL, HCTZ and their known impurities UV spectrums. VAL and HCTZ have wavelength maxima at about 260 - 270 $\mathrm{nm}$ and their known impurities have sufficient absorbance for the measurement. Hence the $265 \mathrm{~nm}$ was selected as suitable wavelength for the estimation of impurities. The UV spectrums of VAL, HCTZ and their impurities has presented in Figure 4(A) \& Figure 4(B).

\subsection{Method Validation}

Validation was performed on the developed analytical method for its acceptable performance to ensure suitability of intend purpose. The validation parameters like accuracy, precision, specificity, detection limit, quantification limit, linearity, range, ruggedness and robustness were executed and established method conditions to meet the requirements to execute the analysis of VAL and HCTZ combination dosage product. Linearity, limit of quantification, limit of detection, precision, intermediate precision at LOQ and percentage recovery of VAL, HCTZ and their impurities were established and presented.

Table 1. Peak details.

\begin{tabular}{cccccc}
\hline Compound & RT (min) & RRT $^{*}$ & RRF (Relative Response Factor) & Resolution & Tailing Factor \\
\hline HCTZ-1 & 11.734 & 0.87 & 1.15 & N/A & 1.22 \\
HCTZ-2 & 12.593 & 0.94 & 0.47 & 2.56 & 1.19 \\
HCTZ & 13.389 & 1.0 & 1.0 & 3.08 & 0.99 \\
HCTZ-3 & 16.476 & 1.23 & 0.58 & 14.85 & 1.06 \\
HCTZ-4 & 18.396 & 1.37 & 1.0 & 11.62 & 1.04 \\
VAL-1 & 22.008 & 0.95 & 1.16 & 23.38 & 1.09 \\
VAL & 23.207 & 1.0 & 1.0 & 5.02 & 1.06 \\
VAL-2 & 32.612 & 1.40 & 0.93 & 25.08 & 1.02 \\
\hline
\end{tabular}

${ }^{*}$ Relative retention times (RRT) for HCTZ-1, HCTZ-2, HCTZ-3 \& HCTZ-4 were calculated against the retention time (RT) of HCTZ and for VAL-1 \& VAL-2 were calculated against the retention time (RT) of VAL. 

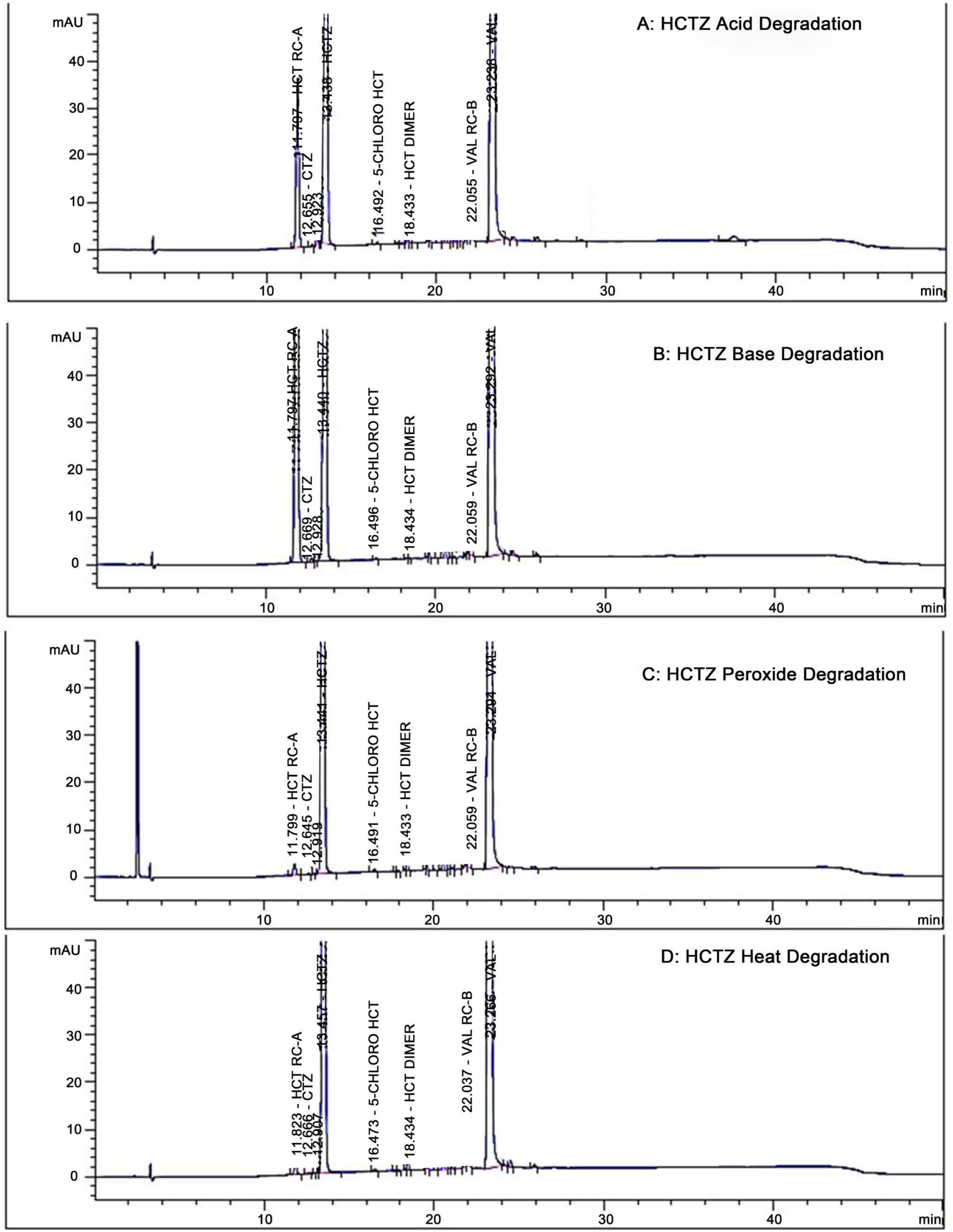

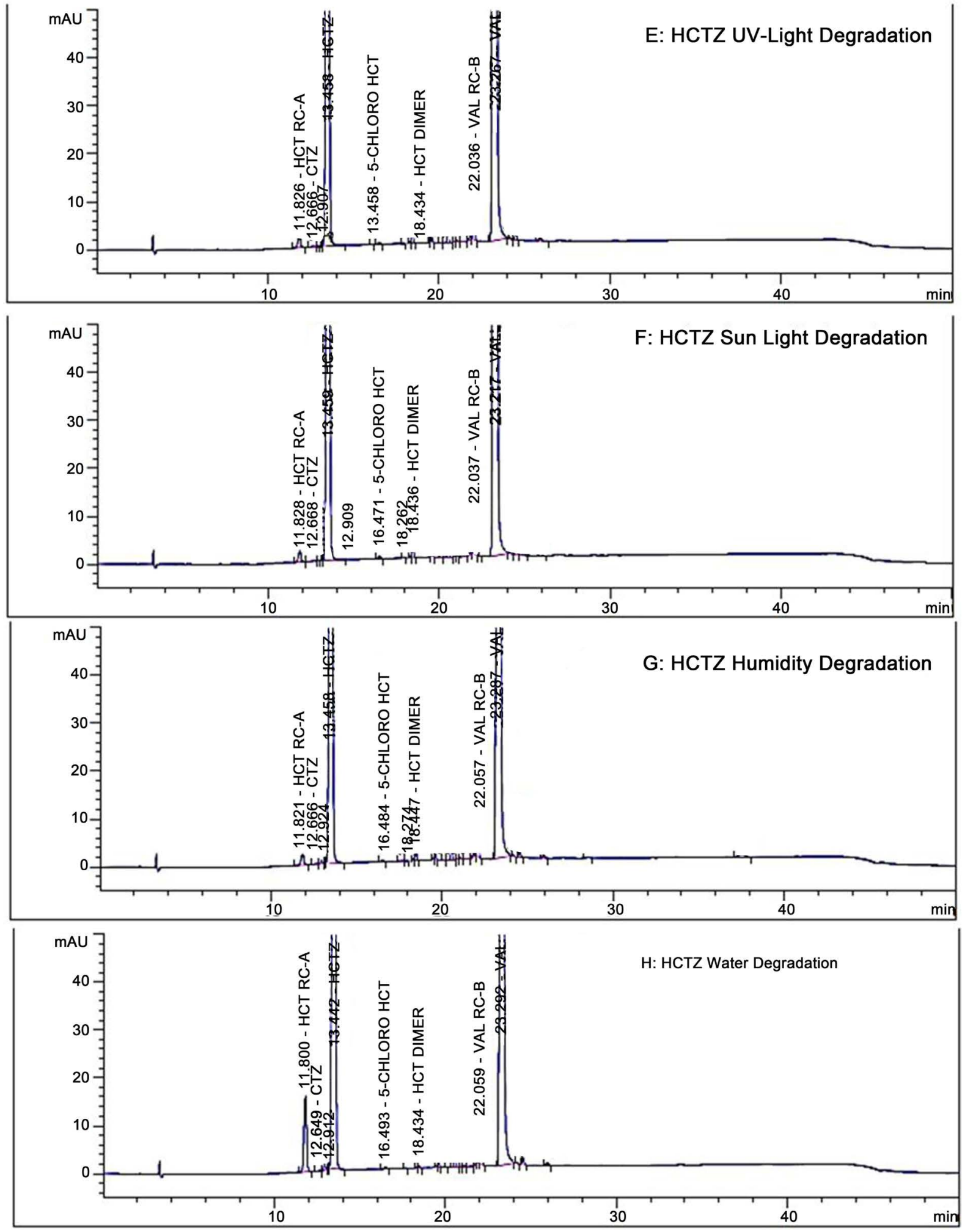

Figure 4. Typical chromatograms of hydrochlorothiazide at $265 \mathrm{~nm}$ (forced degradation study) (A. HCTZ Acid degradation; B. HCTZ Base degradation; C. HCTZ Peroxide degradation and D. HCTZ Heat degradation); Typical chromatograms of hydrochlorothiazide at $265 \mathrm{~nm}$ (forced degradation study) (E. HCTZ UV-Light degradation; F. HCTZ Sun-Light degradation; G. HCTZ Humidity degradation and H. HCTZ Water degradation). 


\subsection{Solution Stability}

The variability in the estimation of VAL and HCTZ impurities were within $\pm 10 \%$ during solution stability experiment. The results from solution stability experiments confirmed that standard and sample solutions were stable up to $48 \mathrm{hrs}$.

\subsection{Specificity: Results of Forced Degradation Studies}

All forced degradation samples were analyzed at an initial concentration $1600 \mu \mathrm{g} \cdot \mathrm{mL}^{-1}$ of VAL and $250 \mu \mathrm{g} \cdot \mathrm{mL}^{-1}$ of HCTZ with LC conditions using PDA detector to ensure the homogeneity and purity of VAL and HCTZ peaks. Under the specificity experiment samples were stressed at various stress conditions and analyzed along with unstressed samples (Figure 5 \& Figure 6). HCTZ degraded significantly at particular conditions. HCTZ-1 \& HCTZ-2 impurities were significantly increased at Acid hydrolysis $(1 \mathrm{~N} \mathrm{HCl}$ at $60^{\circ} \mathrm{C}$ for $12 \mathrm{hr}$ ), Base Hydrolysis $\left(1 \mathrm{~N} \mathrm{NaOH}\right.$ at $60^{\circ} \mathrm{C}$ for $12 \mathrm{hr}$ ) and at water hydrolysis (at $60^{\circ} \mathrm{C}$ for $12 \mathrm{hr}$ ) condition (Figure 6(A), Figure 6(B) \& Figure 6(H)).

a. ACE $5, \mathrm{C} 18 ; 125^{*} 3.0 \mathrm{~mm} ; 5 \mu \mathrm{m}$

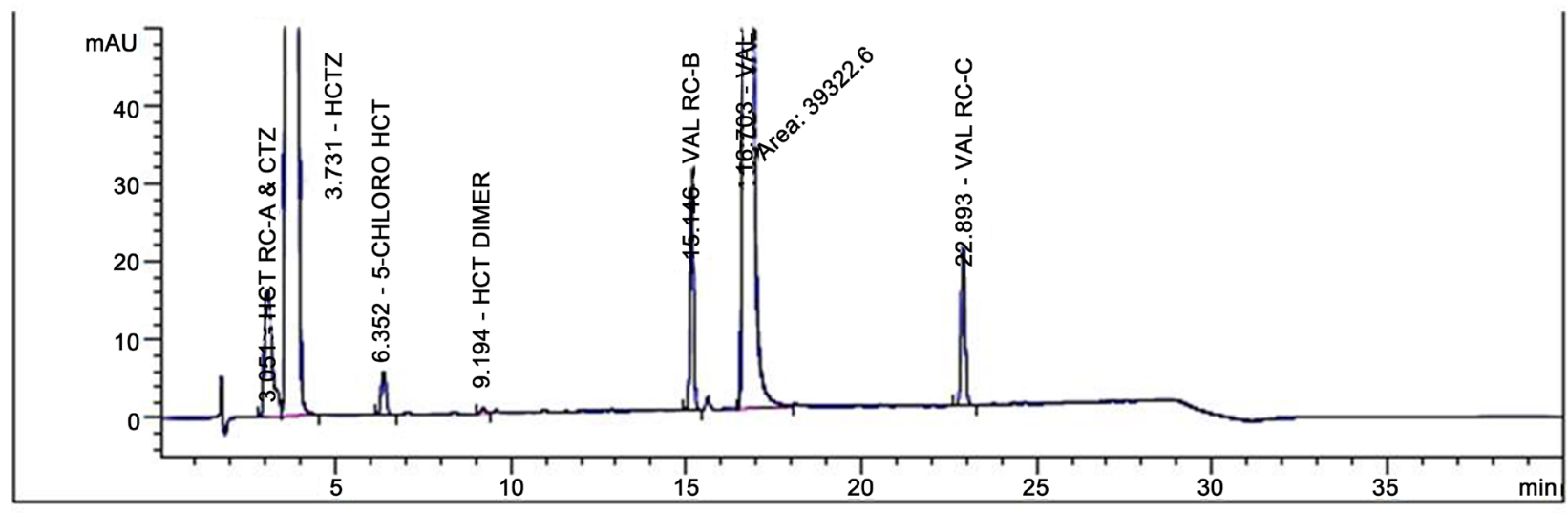

b. Hypersil Gold-C18; $125^{\star} 3.0 \mathrm{~mm} ; 5 \mu \mathrm{m}$

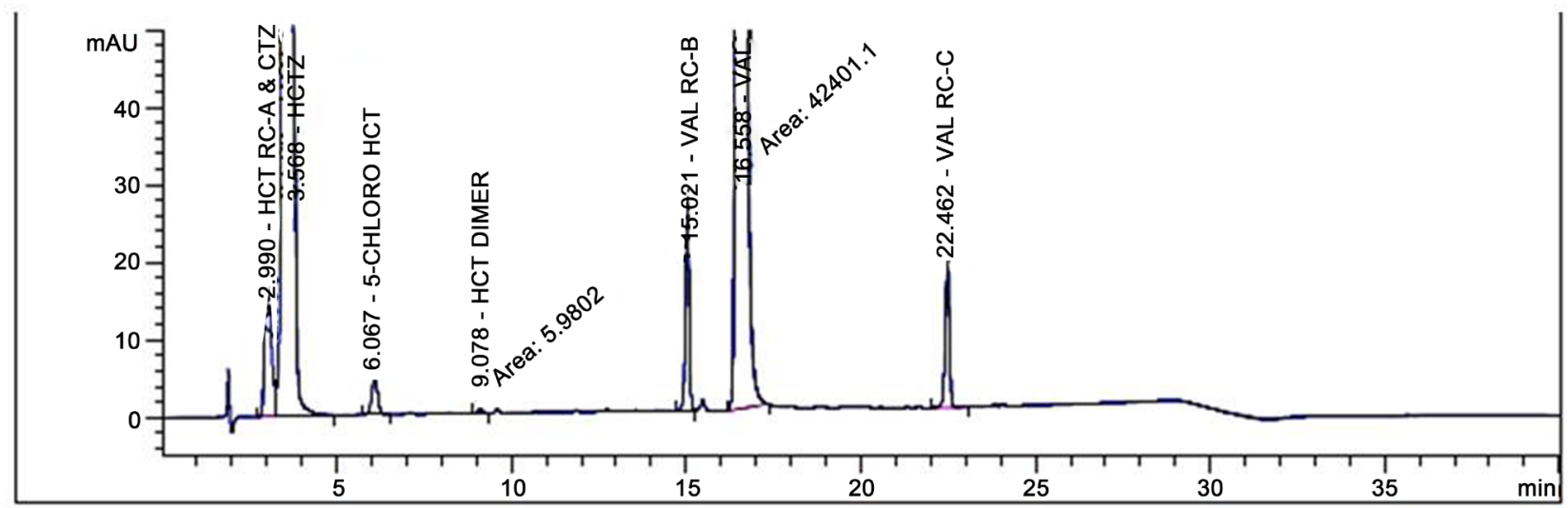

(A) 

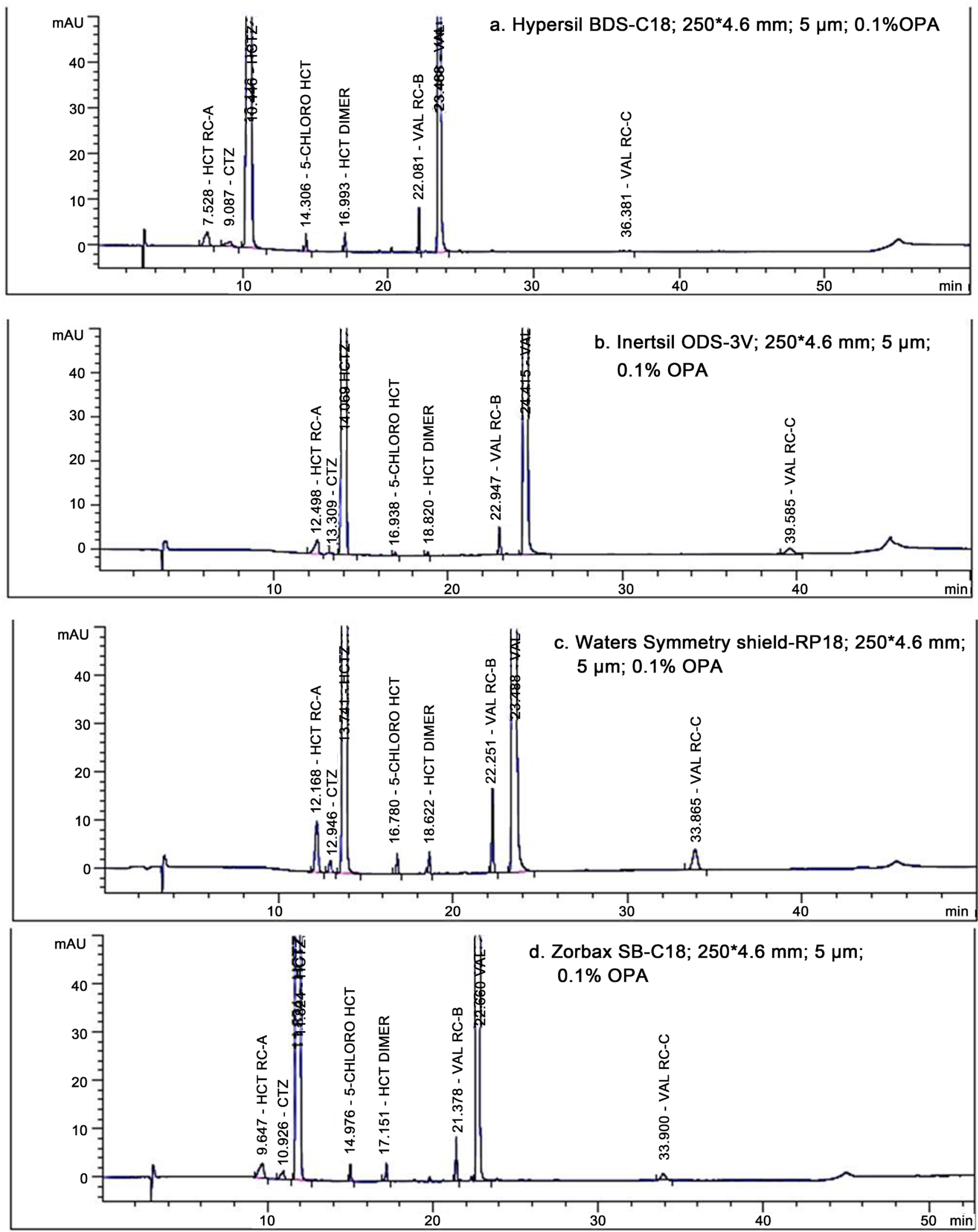

(B) 
a. Hypersil BDS-C18; $250 * 4.6 \mathrm{~mm} ; 5 \mu \mathrm{m} ; 0.1 \%$ TFA

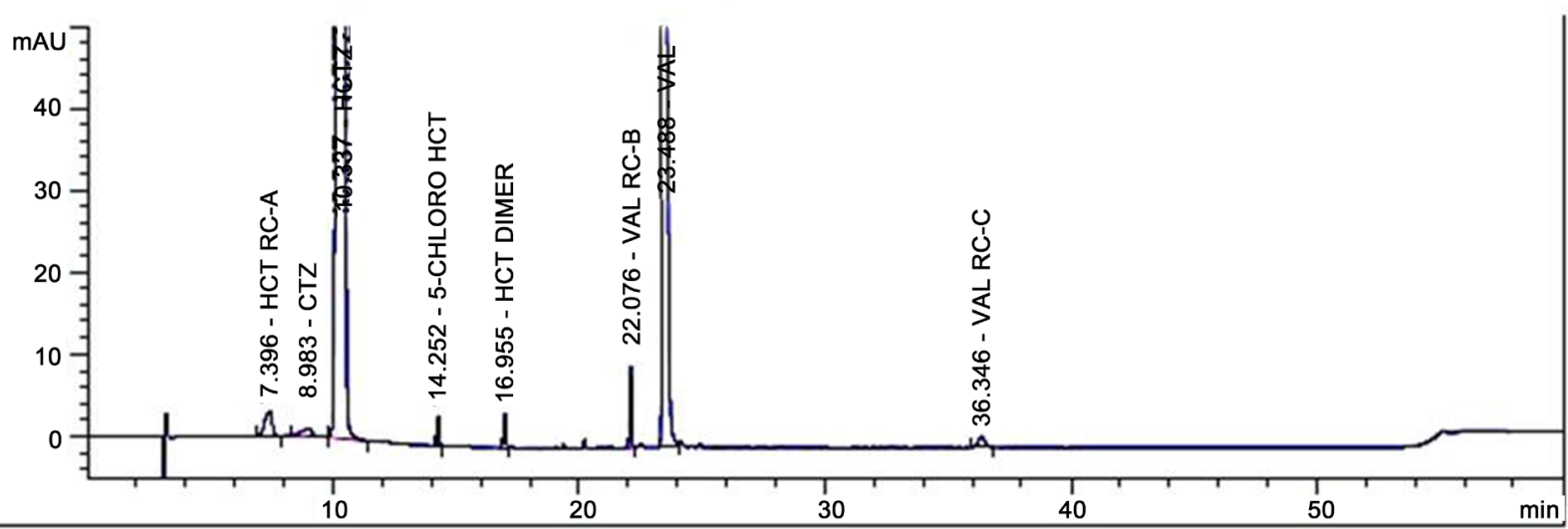

b. Waters Symmetry shield-RP18; $250 * 4.6 \mathrm{~mm}$; $5 \mu \mathrm{m} ; 0.1 \%$ TFA

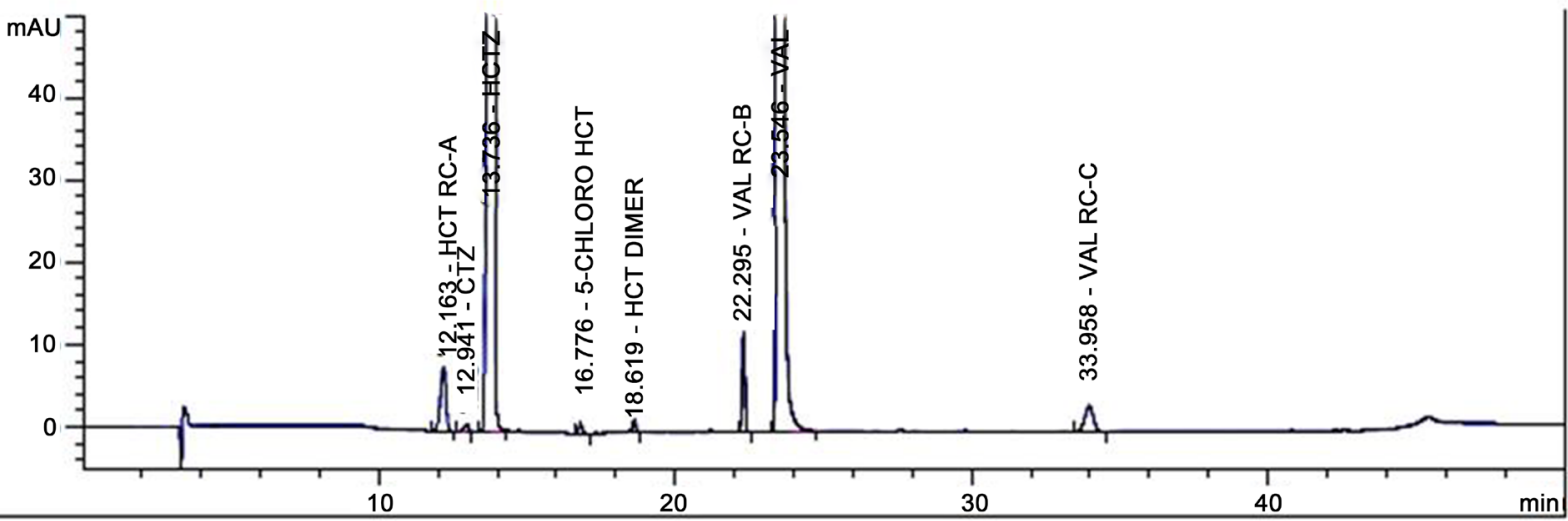

c. Zorbax SB-C18; $250 * 4.6 \mathrm{~mm} ; 5 \mu \mathrm{m} ; 0.1 \% \mathrm{TFA}$

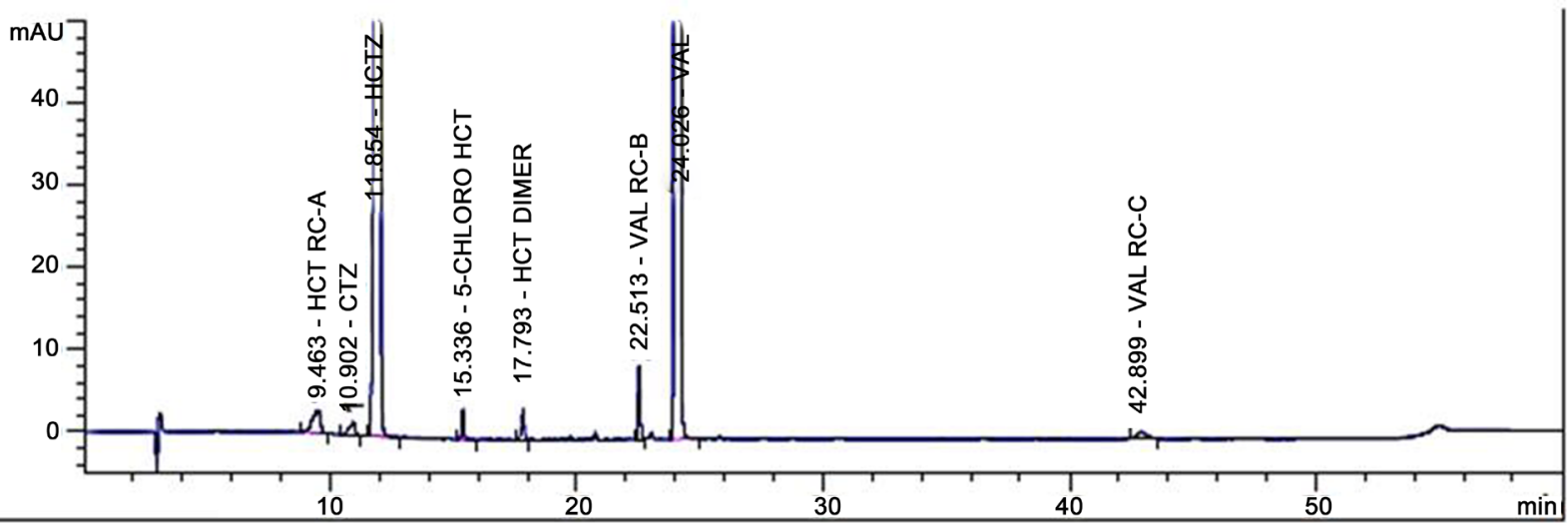

(C)

Figure 5. (A) Method development trial chromatograms column study USP Method (a. ACE 5; C18; $125^{\star} 3.0 \mathrm{~mm} ; 5$ m; b. Hypersil Gold C18; $125^{\star} 3.0 \mathrm{~mm} ; 5 \mu \mathrm{m}$ ); (B) Method development trial chromatograms column study, 0.1\% OPA as Solvent-A (a. Hypersil BDS-C18; $250^{\star} 4.6 \mathrm{~mm} ; 5 \mu \mathrm{m}$; b. Inertsil ODS-3V; $250^{\star} 4.6 \mathrm{~mm} ; 5 \mu \mathrm{m}$; c. Waters Symmetry Shield-RP18; $250^{\star} 4.6 \mathrm{~mm} ; 5 \mu \mathrm{m}$ and d. Zorbax SB-C18; $250^{\star} 4.6 \mathrm{~mm} ; 5 \mu \mathrm{m}$ ); (C) Method development trial chromatograms column study, 0.1\% TFA as Solvent-A (a. Hypersil BDS-C18; $250^{\star} 4.6$ $\mathrm{mm} ; 5 \mu \mathrm{m}$; b. Waters Symmetry Shield-RP18; 250^4.6 mm; $5 \mu \mathrm{m}$ and c. Zorbax SB-C18; $\left.250^{\star} 4.6 \mathrm{~mm} ; 5 \mu \mathrm{m}\right)$. 

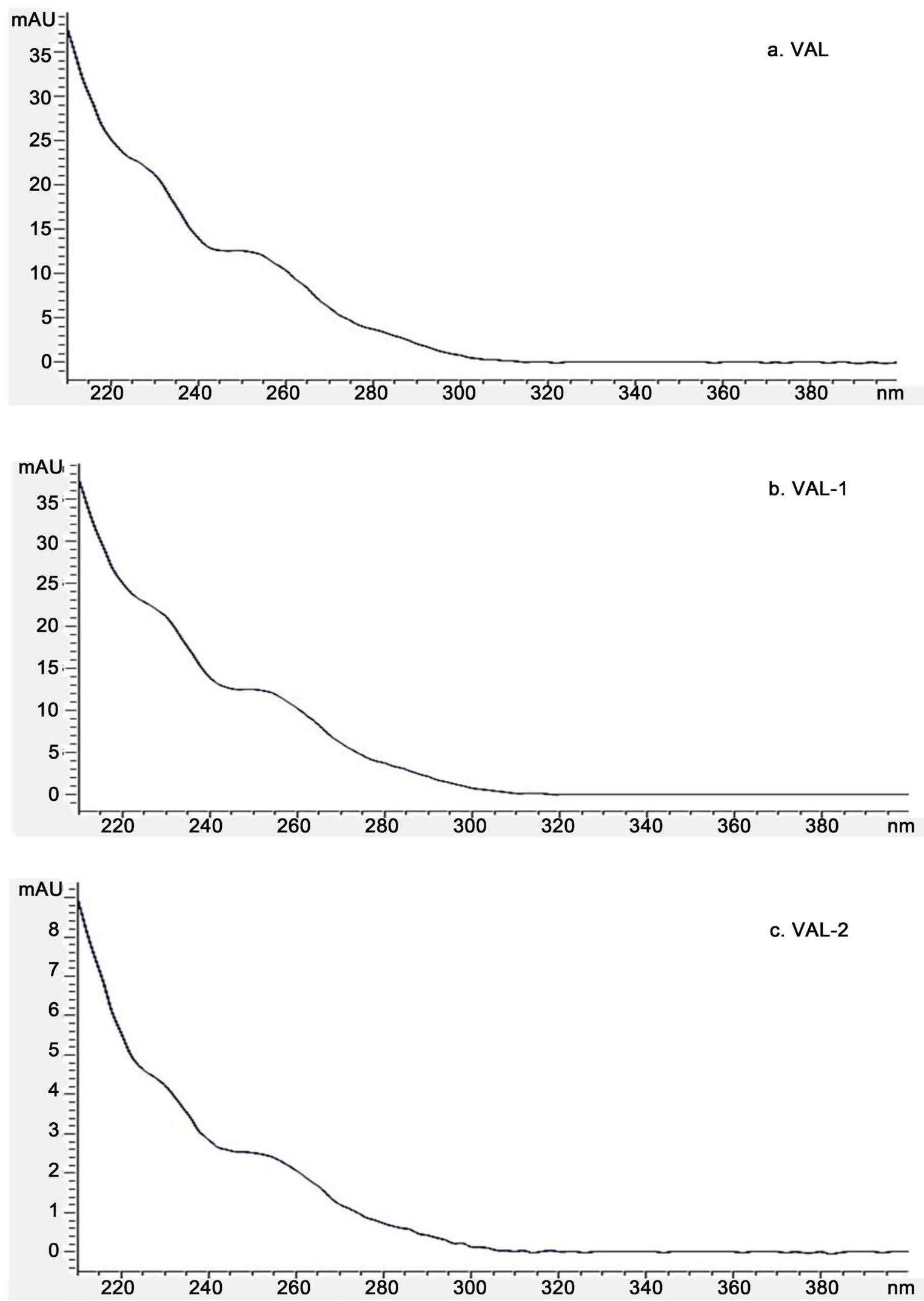

(A) 

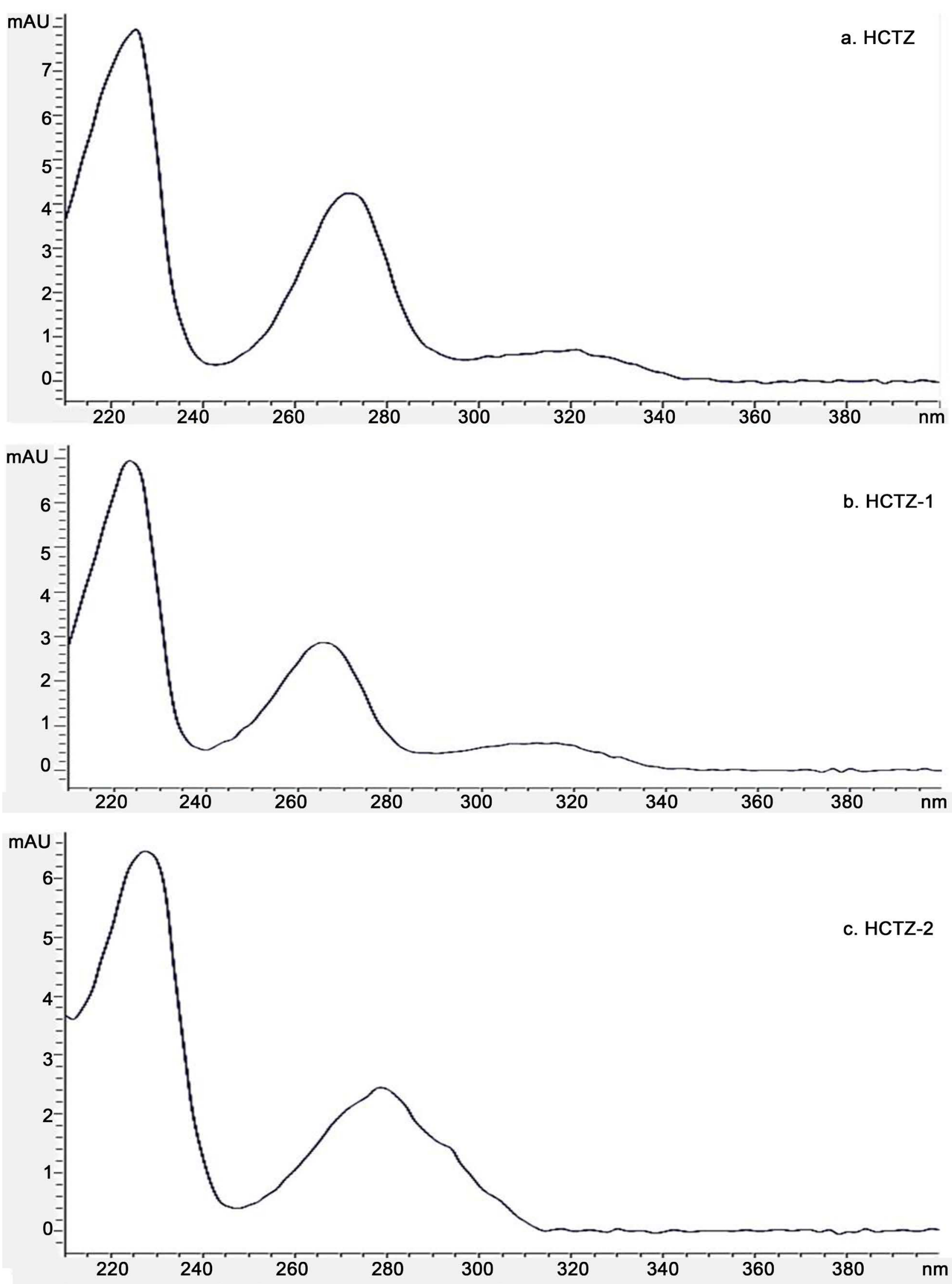

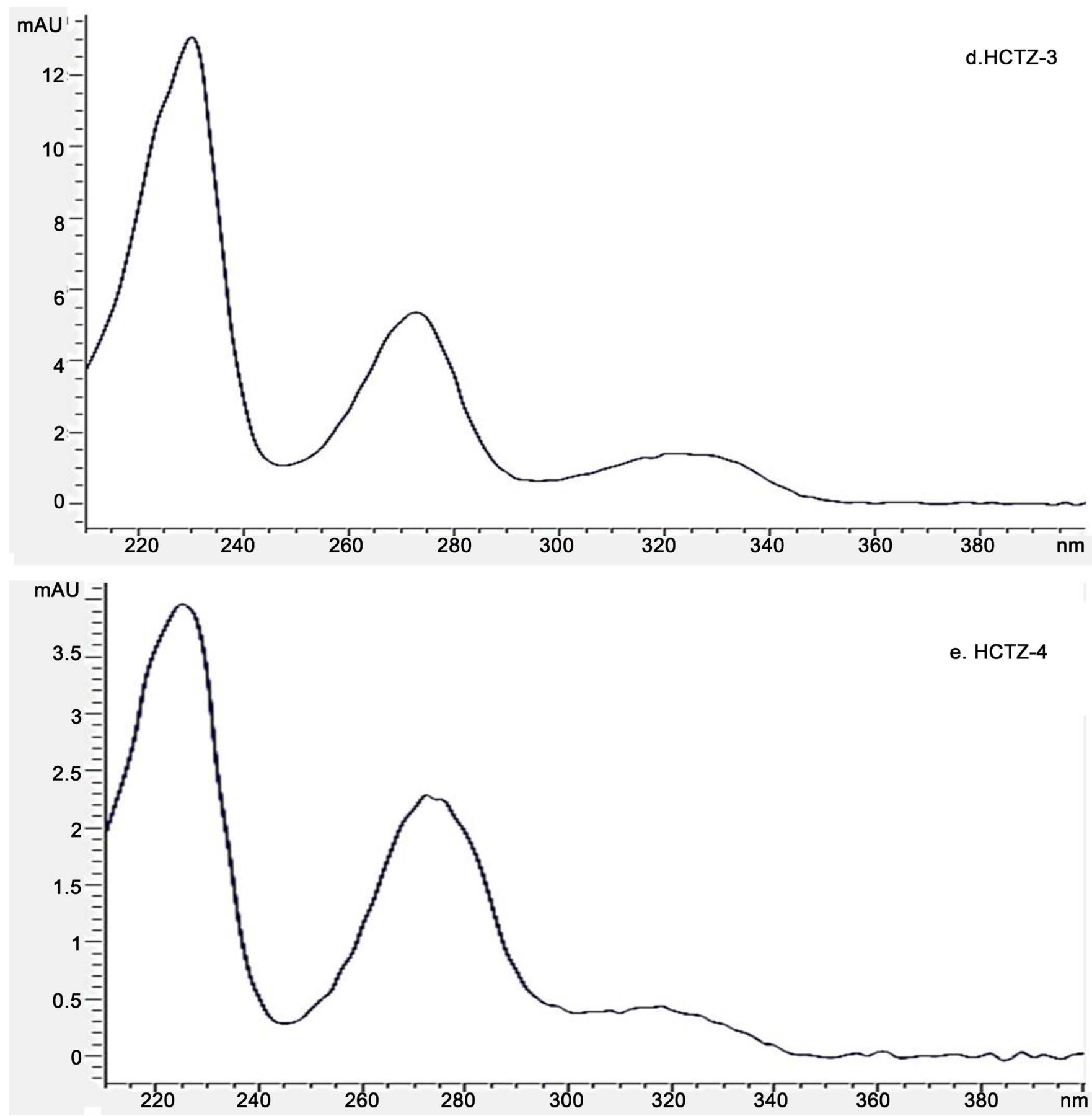

(B)

Figure 6. (A) UV Spectrum of VAL and their impurities (a. VAL; b. VAL-1; c. VAL-2); (B) UV Spectrum of HCTZ and their impurities (a. HCTZ; b. HCTZ-1; c. HCTZ-2); (B) UV Spectrum of HCTZ impurities (d. HCTZ-3; e. HCTZ-4).

The peak purity test result derived from photo diode array detector (PDA) confirmed that VAL and HCTZ peaks were pure and homogeneous in all the analyzed stress conditions and thus confirms the stability-indicating power of the developed method. Results of forced degradation studies were reported in Table 2. 
Table 2. Specificity (results of forced degradation studies).

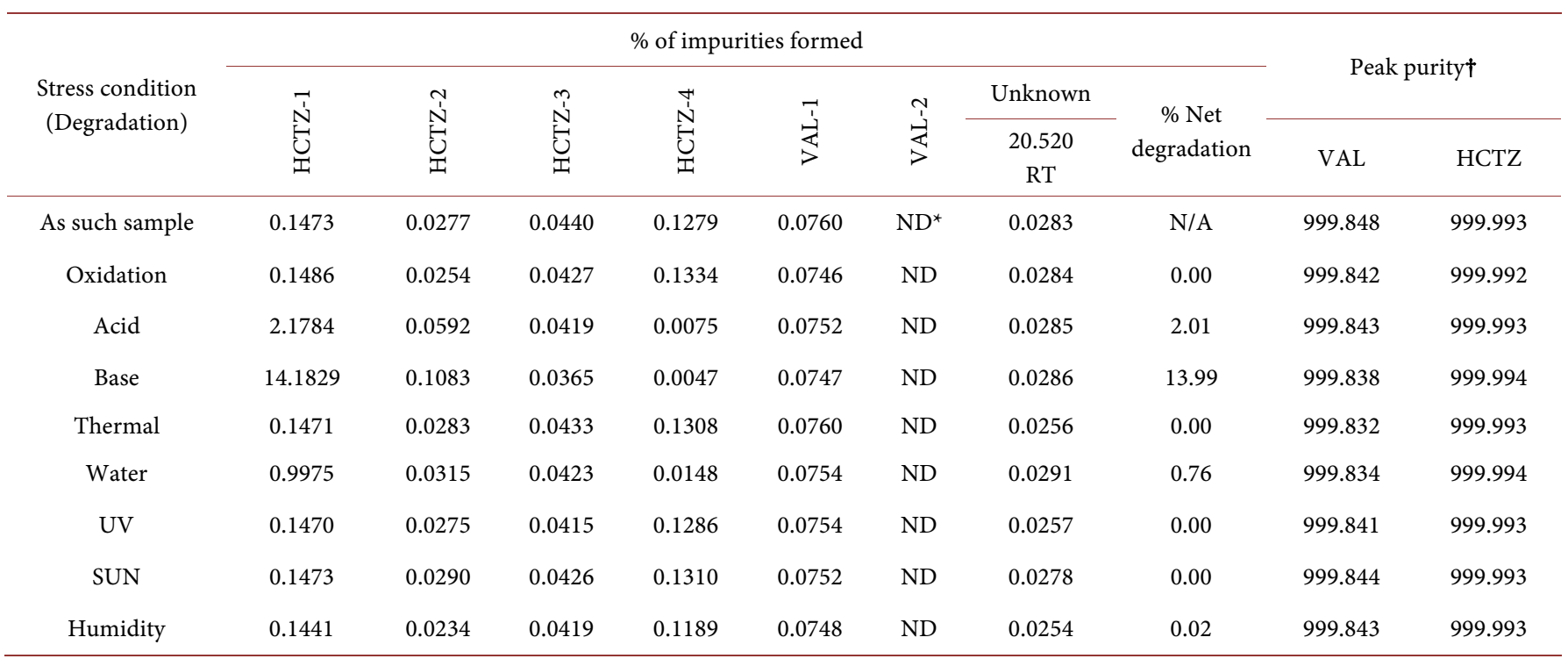

${ }^{*}$ ND-Not Detected; N/A-Not Applicable; $\uparrow$ Peak purity numbers represented as per Agilent Chemstation software algorithm. Peak is pure only if purity value is more than 990 .

\subsection{Linearity}

Linear calibration plot for impurities was obtained over the calibration ranges tested, i.e. LOQ to $200 \%$ for impurities. The correlation coefficient obtained was greater than 0.998 (Table 3). The above result shows that an excellent correlation existed between the peak area and the concentration of all five impurities.

\subsection{Limits of Detection and Quantification}

The limit of detection and limit of quantification values were established based on the signal to noise ratios. Precision at LOQ values for VAL and HCTZ and its five impurities were established and reported in Table 3.

\subsection{Precision}

The result of all the impurities (HCTZ-1, HCTZ-2, HCTZ-3, VAL-1 and VAL-2) in repeatability study was showed less than 15\% RSD for each individual impurity. Data of repeat experiment was showed less than $2.3 \%$ RSD for impurities. These results are conforming good precision of the method. The \% RSD values are presented in Table 3.

\subsection{Accuracy}

The percentage recovery of impurities varied from $97.6 \%$ to $102.4 \%$ in the analysis of impurities. The \% recovery values for VAL and HCTZ and their impurities are found accurate throughout the range selected.

\subsection{Robustness}

In all the deliberate varied chromatographic conditions like flow rate $\left(-0.1 \mathrm{~mL} \cdot \mathrm{min}^{-1}\right.$ 
Table 3. Regression and precision data.

\begin{tabular}{cccccccc}
\hline PARAMETER & VAL & HCTZ & VAL-1 & VAL-2 & HCTZ-1 & HCTZ-2 & HCTZ-3 \\
\hline LOD $(\mu \mathrm{g} / \mathrm{mL})$ & 0.100 & 0.006 & 0.028 & 0.108 & 0.006 & 0.026 & 0.015 \\
LOQ $(\mu \mathrm{g} / \mathrm{mL})$ & 0.303 & 0.019 & 0.085 & 0.327 & 0.017 & 0.080 & 0.047 \\
Correlation coefficient & 0.9999 & 0.9998 & 0.9999 & 0.9999 & 1.0000 & 0.0999 \\
Bias at 100 \% response & 1.0368 & -0.7663 & 0.6896 & 0.5841 & -0.6679 & 0.6185 & 0.18 \\
Precision (\%RSD) & 1.3 & 1.3 & 1.6 & 1.2 & 1.3 & 1.0 & 0.9 \\
Intermediate precision (\%RSD) & 1.2 & 1.4 & 1.3 & 1.9 & 1.5 & 0.8 \\
Precision at LOQ (\%RSD) & 1.3 & 1.0 & 2.3 & 1.5 & 1.2 & 2.2 \\
\hline
\end{tabular}

and $+0.1 \mathrm{~mL} \cdot \mathrm{min}^{-1}$ of $\left.1.0 \mathrm{~mL} \cdot \mathrm{min}^{-1}\right)$ column temperature $\left( \pm 5^{\circ} \mathrm{C}\right.$ of $\left.25^{\circ} \mathrm{C}\right)$ all the analytes were adequately resolved and elution orders remained unchanged. The resolution between all pair compounds was greater than 2.0 and tailing factor for VAL and HCTZ and their impurities was less than 1.5. The variability in the estimation of VAL and HCTZ impurities was within $\pm 10 \%$.

\section{Conclusion}

The rapid gradient RP-HPLC method developed for quantitative analysis of VAL and HCTZ and related substances in pharmaceutical dosage form is precise, accurate, linear, robust and specific. Satisfactory results were obtained from validation of the method. The method is stability-indicating and can be used for routine analysis of production samples to check the stability [23] of VAL and HCTZ in FDC tablet dosage form.

\section{References}

[1] http://www.rxlist.com/diovan-hct-drug.htm

[2] The United States Pharmacopoeia 39 NF34 First Supplement.

[3] The European Pharmacopoeia 8.0.

[4] Macek, J., Klima, J. and Ptacek, P. (2006) Rapid Determination of Valsartan in Human Plasma by Protein Precipitation and High-Performance Liquid Chromatography. Journal of Chromatography B, 832, 169-172. https://doi.org/10.1016/j.jchromb.2005.12.035

[5] Daneshtalab, N., Lewanczuk, R.Z. and Jamali, F. (2002) High Performance Liquid Chromatographic Analysis of Angiotensin II Receptor Antagonist Valsartan Using a Liquid Extraction Method. Journal of Chromatography B, 766, 345-349. https://doi.org/10.1016/S0378-4347(01)00507-2

[6] Takar, S. and Saglik, S. (2002) Comparison of UV and Second Derivative-Spectrophotometric and LC Methods for the Determination of Valsartan in Pharmaceutical Formulation. Journal of Pharmaceutical and Biomedical Analysis, 30, 371-375. https://doi.org/10.1016/S0731-7085(02)00360-6

[7] Rao, K.S., Jena, N. and Rao, M. (2010) Development and Validation of a Specific Stability Indicating High Performance Liquid Chromatographic Method for Valsartan. Journal of Young Pharmacists, 2, 183-189. https://doi.org/10.4103/0975-1483.63166

[8] Niopas, I. and Daftsios, A.C. (2002) A Validated HPLC Method for the Determination of Hydrochlorothiazide in Human Plasma \& Its Application in Pharmacokinetic Studies. 
Journal of Liquid Chromatography \& Related Technologies, 25, 487-494. https://doi.org/10.1081/JLC-120008762

[9] Morra, V., Davita, P., Capra, P., Vincenti, M., Distilo, A. and Botrè, F. (2006) Fast Gas Chromatographic/Mass Spectrometric Determination of Diuretics \& Masking Agents in Human Urine: Development and Validation of a Protective Screening Protocol for Antidoping Analysis. Journal of Chromatography A, 1135, 219-229.

https://doi.org/10.1016/j.chroma.2006.09.034

[10] Hillaert, S. and Van den Bossche, W. (2003) Simultaneous Determination of Hydrochlorothiazide and Several Angiotensin-II-Receptor Antagonists by Capillary Electrophoresis. Journal of Pharmaceutical and Biomedical Analysis, 31, 329-339. https://doi.org/10.1016/S0731-7085(02)00643-X

[11] Satana, E., Altinay, S., Goger, N.G., Ozkan, S.A. and Senturk, Z. (2001) Simultaneous Determination of Valsartan and Hydrochlorothiazide in Tablets by First-Derivative Ultraviolet Spectroscopy and LC. Journal of Pharmaceutical and Biomedical Analysis, 25, 10091013. https://doi.org/10.1016/S0731-7085(01)00394-6

[12] Antil, P., Kaushik, D., Jain, G., Srinivas, K.S. and Thakur, I. (2013) UPLC Method for Simultaneous Determination of Valsartan \& Hydrochlorothiazide in Drug Products. Journal of Chromatography \& Separation Techniques, 4, 182.

[13] Gonzalez, L., Lopez, J.A., Alonso, R.M. and Jimenez, R.M. (2002) Fast Screening Method for the Determination of Angiotensin II Receptor Antagonist in Human Plasma by High Performance Liquid Chromatography with Fluorimetric Detection. Journal of Chromatography A, 949, 49-60. https://doi.org/10.1016/S0021-9673(01)01496-0

[14] Liu, F., Zhang, J., Xu, Y., Gao, S. and Guo, Q. (2008) Simultaneous Determination of Hydrochlorothiazide and Valsartan in Human Plasma by Liquid Chromatography/Tandem Mass Spectrometry. Analytical Letters, 41, 1348-1365. https://doi.org/10.1080/00032710802119186

[15] Li, H., Wang, Y., Jiang, Y., Tang, Y., Wang, J., Zhao, L. and Gu, J. (2007) A Liquid Chromatography/Tandem Mass Spectrometry Method for the Simultaneous Quantification of Valsartan and Hydrochlorothiazide in Human Plasma. Journal of Chromatography B, Analytical Technologies in the Biomedical and Life Sciences, 852, 436-442. https://doi.org/10.1016/j.jchromb.2007.02.014

[16] Hillaert, S. and Bossche, W. (2002) Optimization and Validation of a Capillary Zone Electrophoretic Method for the Analysis of Several Angiotensin-II-Receptor Antagonists. Journal of Chromatography $A$, 979, 323-333. https://doi.org/10.1016/S0021-9673(02)01247-5

[17] Hillaert, S., De Beer, T.R.M., De Beer, J.O. and Van den Bossche, W. (2003) Optimization and Validation of a Micellar Electrokinetic Chromatographic Method for the Analysis of Several Angiotensin-II-Receptor Antagonists. Journal of Chromatography A, 984, 135-146. https://doi.org/10.1016/S0021-9673(02)01832-0

[18] Anandakumar, K. and Jayamariappan, M. (2011) Absorption Correction Method for the Simultaneous Estimation of Amlodipine Besylate, Valsartan and Hydrochlorothiazide in Bulk and in Combined Tablet Dosage Form. International Journal of Pharmacy and Pharmaceutical Sciences, 3, 23-27.

[19] Kharoaf, M., Malkieh, N., Abualhasan, M., Shubitah, R., Jaradat, N. and Zaid, A.N. (2012) Tablet Formulation and Development of a Validated Stability Indicating Method for Quantification of Valsartan and Hydrochlorothiazide Combination. International Journal of Pharmacy and Pharmaceutical Sciences, 4, 284-290.

[20] Zhang, H. and Ding, S.-T. (2012) Determination of Related Substance in Valsartan and Hydrochlorothiazide Dispersible Tablets by HPLC Gradient Elution Method. Food and 
Drug, 14, 42-44.

[21] Chen, X.-W. and Liu, A.-L. (2012) Determination of Related Substances in Valsartan Hydrochlorothiazide Tablets. Qilu Pharmaceutical Affairs, 31.

[22] International Council on Harmonization (ICH) (2005) Validation of Analytical Procedures: Text and Methodology Q2(R1). IFPMA, Geneva.

[23] International Council on Harmonization (ICH) (2003) Stability Testing of New Drug Substances and Products Q1A(R2). IFPMA, Geneva.

\section{Submit or recommend next manuscript to SCIRP and we will provide best service} for you:

Accepting pre-submission inquiries through Email, Facebook, LinkedIn, Twitter, etc. A wide selection of journals (inclusive of 9 subjects, more than 200 journals)

Providing 24-hour high-quality service

User-friendly online submission system

Fair and swift peer-review system

Efficient typesetting and proofreading procedure

Display of the result of downloads and visits, as well as the number of cited articles

Maximum dissemination of your research work

Submit your manuscript at: http://papersubmission.scirp.org/

Or contact ajac@scirp.org 